\title{
OPEN SCHOOLING WITH INQUIRY MAPS IN NETWORK EDUCATION: supporting Responsible Research and Innovation (RRI) and fun in
} learning

\author{
Alexandra Okadal \\ Luziana Quadros da Rosa² \\ Márcio Vieira de Souza 3
}

\begin{abstract}
This article discusses the open schooling approach which has been promoted by the European Commission for preparing learners in cooperation with partners to develop real-world issue projects and shape a desirable future together. This approach is designed to engage all participants with RRI - Responsible Research and Innovation (EC, 2015). The objective of RRI is to align research and innovation with societal needs and sustainable development goals (UNESCO, 2015) through the interaction of researchers with society. Open schooling for RRI is considered an interactive approach to help youth develop knowledge, skills, attitude and values for the $21 \mathrm{st}$ century. This study presents some contributions of using inquiry mapping (OKADA, 2006) as a participatory research-action method to engage multi-partners in an open network. This exploratory study supported by a set of examples from the literature provides recommendations for developing inquiry-maps for open schooling in network projects and facilitates fun in learning.
\end{abstract}

Keywords: Open schooling. Inquiry maps. Responsible Research and Innovation. Network education. Fun and learning.

\section{ESCOLARIZAÇÃO ABERTA COM MAPAS DE INVESTIGAÇÃO NA EDUCAÇÃO EM REDE: apoiando a Pesquisa e Inovação Responsáveis (RRI) e a diversão na aprendizagem}

\footnotetext{
${ }^{1} \mathrm{PhD}$ in Education. Senior Fellow of Higher Education Academy (UK), Educational researcher at the Faculty of Wellbeing, Education \& Language Studies - The Open University, Milton Keynes, Reino Unido. Orcid ID: http://orcid.org/0000-0003-1572-5605. E-mail: alexandra.okada@gmail.com.

2 MA in Information and Communications Technology. PhD student at the Graduate Program in Knowledge Engineering Management at the Universidade Federal de Santa Catarina, Florianópolis - SC, Brazil. Orcid ID: http://orcid.org/0000-0002-5689-4184. E-mail: cpead.bpi.luziana@gmail.com.

${ }_{3}^{3} \mathrm{PhD}$ in Production Engineering. Professor at the Graduate Program in Knowledge Engineering Management at the Universidade Federal de Santa Catarina, Florianópolis - SC, Brazil. Orcid ID: http://orcid.org/0000-0002-0165-4036. E-mail: marciovieiradesouza@gmail.com
} 


\title{
RESUMO
}

Este artigo discute a Escolarização Aberta que é uma abordagem promovida pela Comissão Europeia para preparar os estudantes em cooperação com parceiros para desenvolver projetos sobre questões do mundo real e construir juntos um futuro desejável. Essa abordagem foi projetada para envolver todos os participantes na RRI - Pesquisa e Inovação Responsáveis (EC, 2015). O objetivo da RRI é alinhar pesquisa e inovação com as necessidades da sociedade e com os objetivos de desenvolvimento sustentável (UNESCO, 2015) por meio da interação de pesquisadores com cidadãos. A Escolarização Aberta para a RRI é considerada uma abordagem interativa para ajudar os jovens a desenvolver conhecimentos, habilidades, atitudes e valores para o século 21. Este estudo apresenta algumas contribuições quanto ao uso de mapas de investigação (OKADA, 2006) como método participativo de pesquisa-ação para envolver múltiplos parceiros em uma rede aberta. Este estudo exploratório, apoiado por um conjunto de exemplos da literatura, fornece recomendações para o desenvolvimento de mapas de investigação para projetos de escolarização aberta em rede e facilita a diversão na aprendizagem.

Palavras-chave: Escolarização aberta. Mapas de investigação. Pesquisa e inovação responsáveis. Educação em rede. Diversão e aprendizagem.

\section{ESCOLARIDAD ABIERTA CON MAPAS DE INVESTIGACIÓN EN EDUCACIÓN EN}

\author{
RED: en Apoyo de la Investigación y Innovación Responsables (RRI) y \\ diversión en la aprendizaje
}

\section{RESUMEN}

Este artículo aborda el enfoque de la escolaridad abierta que fue promovido por la Comisión Europea para preparar a los estudiantes en cooperación con socios para desarrollar proyectos sobre problemas del mundo real y construir juntos un futuro deseable. Este enfoque fue diseñado para involucrar a todos los participantes en RRI - Investigación e innovación responsables (EC, 2015). El objetivo de RRI es alinear la investigación y la innovación con las necesidades de la sociedad y con los objetivos del desarrollo sostenible (UNESCO, 2015) a través de la interacción de los investigadores con los ciudadanos. La escolaridad abierta para RRI se considera un enfoque interactivo para ayudar a los jóvenes a desarrollar conocimientos, habilidades, actitudes y valores para el siglo 21. Este estudio presenta algunas contribuciones del uso de mapas de investigación (OKADA, 2006) como un método de investigación de acción participativa para involucrar a múltiples socios en una red abierta. Este estudio exploratorio, respaldado por un conjunto de ejemplos de la literatura, proporciona recomendaciones para el desarrollo de mapas de investigación para proyectos de la escolaridad abierta en red y facilita la diversión en el aprendizaje.

Palabras clave: Escolaridad abierta. Mapas de investigación; Investigación e innovación responsables. Educación en red. Divertido y aprendizaje. 


\section{INTRODUCTION NETWORK EDUCATION}

The contemporary world dominated by science and technology requires a scientifically informed network society (Castells, 2010) with scientifically literate networked learners and educators (EC, 2015). Network education with new pedagogical approaches are needed to equip intergeneration of responsible citizen and innovative researchers. Our generation must be prepared to face local and global challenges, including known and unknown socio-scientific issues that are increasingly more complex, compressed in space and time, interconnected and borderless (Holst 2006; Brydon, 2011) that affect our life in the Earth, for example, global warming, environmental destruction and new pandemic diseases such as the COVID-19.

The network education, which is part of network societies (Castells, 2010) has a "macro challenge" of promoting the interconnected learning that integrates formal curriculum, non-formal educational resources and informal contexts with local and global scenarios; including real life issues, fresh data and topical knowledge as well through digital, non-digital and hybrid environments (Okada \& Rodrigues, 2018).

Networked education involves a network society interconnected with network sciences (Rosa, Silva, Müller, Spanhol \& Souza 2018; Souza, 2015). It has become increasingly relevant for building a more interactive, interconnected, inclusive and innovative, education aligned with network societies' needs, priorities and expectations for a sustainable world. This alignment of science with and for society is the core meaning of RRI Responsible Research and Innovation (EC, 2015). For learners to be able to contribute to this alignment, the novel approach open schooling (EC, 2015) has emerged to promote the cooperation between schools, universities and STEM enterprises. To establish open schooling, partners bring real life scenarios as well opportunities for networked learners to learn with distinctive societal actors for example, researchers, professionals and community-members. 
A key challenge of open schooling is to foster scientific literate citizens and increase Youth interests in scientific careers, research and innovation (Ryan, 2015; EC 2015). Open schooling (OS) is an approach introduced by the European Commission to promote science education for responsible citizenship (Ryan, 2015). Its aim is to support schools to prepare students as active participants in real-life projects in cooperation with experts, researchers, families, educators and local communities to shape a better future together. It is designed to integrate formal and informal learning using learners-centred methods such as project-based learning, community problem-solving and participatory-action research with relevant world-issues. Its purpose is to empower all learners to develop relevant knowledge, skills and attitudes.

This paper argues that network theories, methodologies and technologies in education should be used to develop meaningful approaches for learning and teaching in partnerships and in network supported by network thinking. Network thinking is a cognitive process supported by concepts and methods of network science, which is relevant for student to identify problems and seek for relevant knowledge and solutions. The network thinking (Okada, 2008) enables learners to explore a socioscientific issue by "describing its constituent parts (in this case: networks), elaborating on those parts from multiple perspectives, and arriving at a more comprehensive whole" (Ferguson, 2019, p. 7).

This paper considers that open schooling underpinned by network education for RRI requires educating learners with interconnected science capital (Archer, Dawson, DeWitt, Seakin \& Wong, 2015), which integrates knowledge, skills, attitudes, values and partnerships. Science capital and Scientific literacy in (inter)action are vital for learners with societal partners to shape a desirable future.

For those interconnections and interactions to occur, the network education with open schooling has also a "micro challenge" of preparing students in more holistic way with cognitive and non-cognitive abilities 
including soft and hard skills for them being able to interact, cooperate and learn with distinctive partners.

The cooperation with distinctive actors requires learners to acquire conceptual language, reasoning skills and fun participatory approaches that will help them interact with experts and civil society communities and learn in more meaningful and enjoyable way. Students' interconnected knowledge, competences and mindset which includes deep fun for deeper learning are necessary to enable them cocreate actions responsibly with intrinsic engagement for fulfilling accomplishment, for them to explore, understand and shape their network knowledge towards a desirable future collaboratively (Okada, 2020, p. 3).

The key contribution of this paper is providing a method "inquiry mapping" to support network thinking with principles examples and practices from previous studies (Ramos et. al., 2019; Rocha et. al., 2018; Okada, 2014) analysed under the novel lens of open schooling in network; in particular to be used in the context of network education for RRI (EC, 2015) and support learning with fun. Deep fun refers to the intrinsic motivation for fulfilling accomplishment in which students are deeply involved with the joy of learning and achieving higher challenges and goals for self-transformation (OKADA, 2020).

The paper focuses on Network thinking practiced by students with inquiry based learning (Okada, 2008; Okada, 2010) to enhance a set of inquiry based learning skills for RRI : devising research questions, interrogating sources, using ethics, analysing data, drawing conclusions, examining consequences, estimating risks, critiquing claims, justifying views and communicating findings; using digital participatory technologies (Okada \& Sherborne, 2018).

\section{NETWORK THINKING WITH INQUIRY MAPPING}

To facilitate open schooling, the inquiry mapping method can be used by students supported by teachers and other partner to identify, examine and solve challenges that affects individuals, communities and the globe. 
Inquiry Mapping aims to guide learning communities to find relevant socio-scientific issues supported by partners and their recommended sources all in network. This method consists of three cyclical phases with interconnected spaces, see Figure 1, (Okada, 2010).

FIGURA 1 - Inquiry mapping

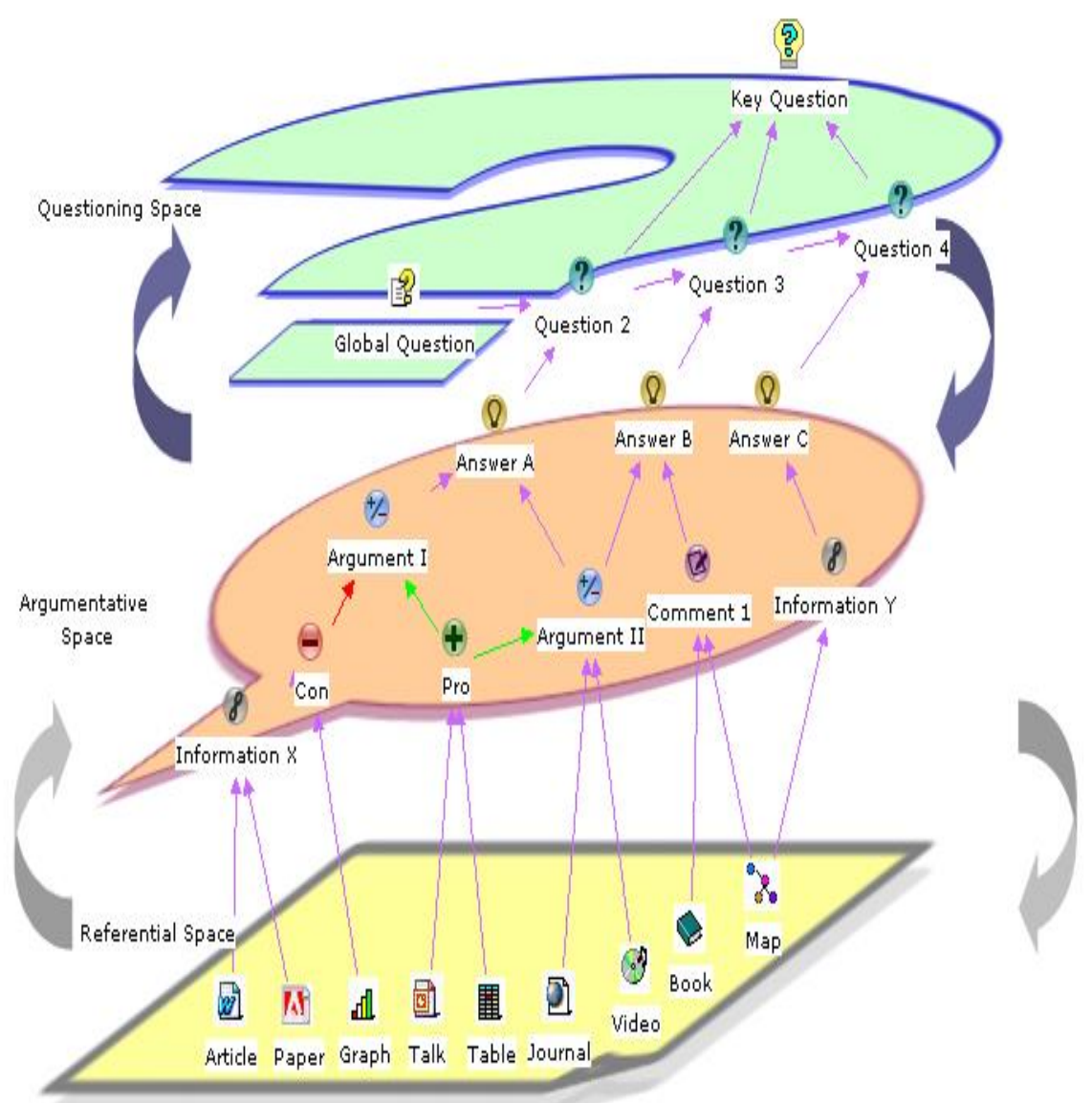

Source: Okada, 2010. Software tool: Compendium

1. Referential space includes a network of writers and their writtendocuments from scientific journals, science-in-the-news, academic repositories and information-in-the-media. This network enables facilitators to create global questions to initiate the second phase.

2. Argumentative space includes a network of communityrepresentatives and their narrative-views about global questions. This network enables the cocreation of local questions to initiate the third phase.

3. Questioning space includes a network of thematic questions for community-members to select, extend or add new ones, including 
partners available to support participatory-action projects led by community members and or participatory-research informed.

Networking thinking through Inquiry mapping aims to help participants identify, connect and interpret key issues, ideas, concepts, data and arguments from their practices and research sources through suggestions provided by all partners with the support of researchers, peers and educatorsfacilitators. Inquiry mapping draws on the work of Jonassen (2000), who defined some principles to foster three sets of thinking skills (Okada, 2010):

- Content/Basic Thinking represents the ability to make sense of accepted information, declarative and explicit knowledge. It refers to the skill of interpret general knowledge and common sense information. Content basic thinking requires learning and retrieving what has been learned.

- Critical Thinking represents the dynamic process of mapping knowledge in meaningful and usable ways though analysis, evaluation and connections. It integrates important skills such as evaluating the process by appropriate criteria analysing interrelationships among relevant elements mapped through connections and recognising gaps, vagueness and misunderstandings.

- Creative Thinking shows the ability to go beyond accepted knowledge to create new questions and reconstruct new knowledge. Creative thinking must be connected to content thinking and critical thinking in order to integrate existing knowledge with the skill of innovative thinking.

\section{Inquiry Mapping principles}

Inquiry Mapping method is supported by inquiry-based learning, which became an important approach to engage students in research projects. Its core purpose is to help learners act as critical thinkers for managing their own investigation rather than act as passive receivers of content. 
Freire (1967) points out that critical thinking is an important skill for not only apprehending meaning, knowledge and truth of the reality, but also making decisions, implementing actions and improving results provoking changes. To be critical, it is necessary to think-act-reflect aiming for improvements (praxis). It also involves reading and writing the world - not only identifying words, but also understanding their meanings, reasons, consequences, aims, context, references and evidence.

Inquiry-based learning has been considered a complex process. Teachers as research facilitators need to provide learners with strategies, tools and guidance by helping them apply what they know or are learning in problem-based activities (Edelson, 2001; Hmelo-Silver, Duncan \& Chinn, 2007). Inquiry-based learning requires students to develop several skills.

In order to construct knowledge during their investigation, students must be able to:

1. Formulate key questions.

2. Select relevant information to address the main issues.

3. Identify new knowledge and make sense in order to construct meanings.

4. Choose appropriate methods for inquiry.

5. Develop possible solutions and draw conclusions.

6. Get feedback and points of view to evaluate the process and products.

Participatory research approaches are also framed as ongoing and collaborative process of raising significant questions, integrating relevant information and generating acceptable lines of reasoning grounded on scientific assumptions and bodies of knowledge (Veerman, 2003). Inquiry map is a methodological approach to facilitate participatory-action research. It is based on six mapping techniques described in the following table (Table 1). 
TABLE 1 - Genres of knowledge map - Knowledge Cartography

\begin{tabular}{|c|c|c|}
\hline Mapping techniques & Aims & Freeware Tools \\
\hline $\begin{array}{c}\text { Concept Mappings } \\
\text { (Novak, 1998) }\end{array}$ & to organise concepts & Cmap Tools \\
\hline $\begin{array}{c}\text { Mind Mapping } \\
\text { (Buzan, 1993) }\end{array}$ & to generate ideas & Lucidchart \\
\hline $\begin{array}{c}\text { Web Mapping } \\
\text { (Okada \& Zeiliger, 2003) }\end{array}$ & to collect web resources \\
\hline $\begin{array}{c}\text { Issue Mapping } \\
\text { (Conklin, 2005) }\end{array}$ & to structure discussions & Compendium \\
\hline $\begin{array}{c}\text { Argument Mapping } \\
\text { (Van Gelder 2002) }\end{array}$ & to develop argumentation \\
\hline $\begin{array}{c}\text { Evidence-based dialogue } \\
\text { mapping (Okada, 2008) }\end{array}$ & $\begin{array}{c}\text { To develop scientific } \\
\text { thinking }\end{array}$ & $\begin{array}{c}\text { Compendium } \\
\text { LiteMap }\end{array}$ \\
\hline
\end{tabular}

Updated from Source: Okada, 2014.

Mapping knowledge for inquiry projects aims to help users mediate the process of abstracting in its Latin conception "abstractere", which means "take it from" the external world, to concreteness give it back to the world, mapped, interpreted, modified by critical thinking (Okada, 2006).

Interpreting knowledge from maps also help students visualise and identify important structures or steps around problem-solution format such as: generalisation, enumerations, sequence, classification and, compare and contrast (Cook \& Mayer, 1988).

Inquiry maps can be applied in several stages of a research project to make thinking visible by drawing out components and lines of reasoning. These inquiry pathways provide researchers representational guidance to interpret and construct meanings by visualising key components and their connections.

McTighe (1992, p. 183) also point out that graphical representations "have proven to be effective tools for enhancing thinking and promoting meaningful learning by helping teachers and students to organise information, generate many ideas, represent abstract concepts, illustrate relationships, relate new information to prior knowledge, store and retrieve information, and assess thinking and learning". 
FIGURE 2 - Inquiry Cycle

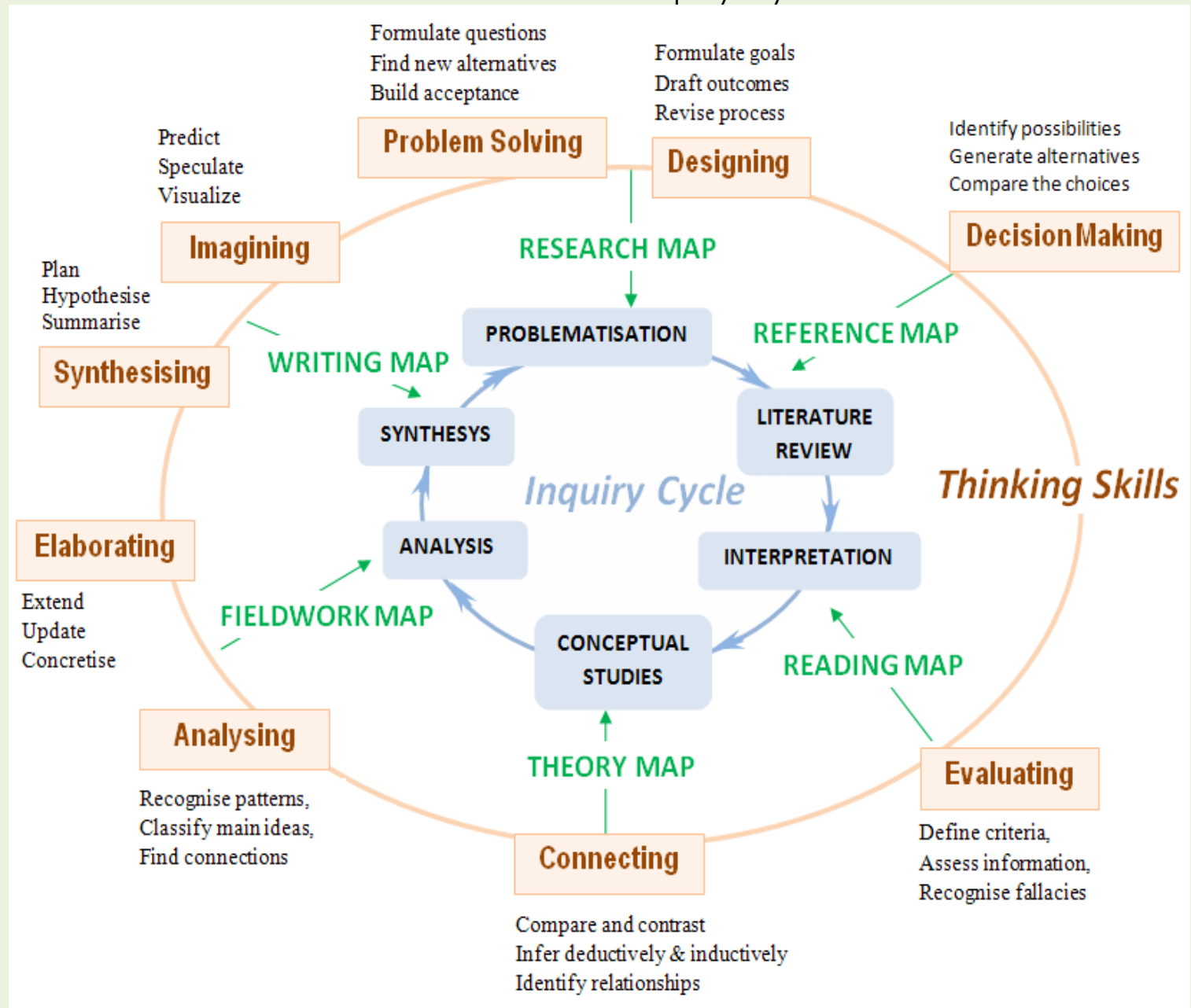

Figure 2 describes six kinds of inquiry maps (Okada, 2006) which can be used to develop six stages of an open schooling project supported by network thinking (Jonassen, 2000).

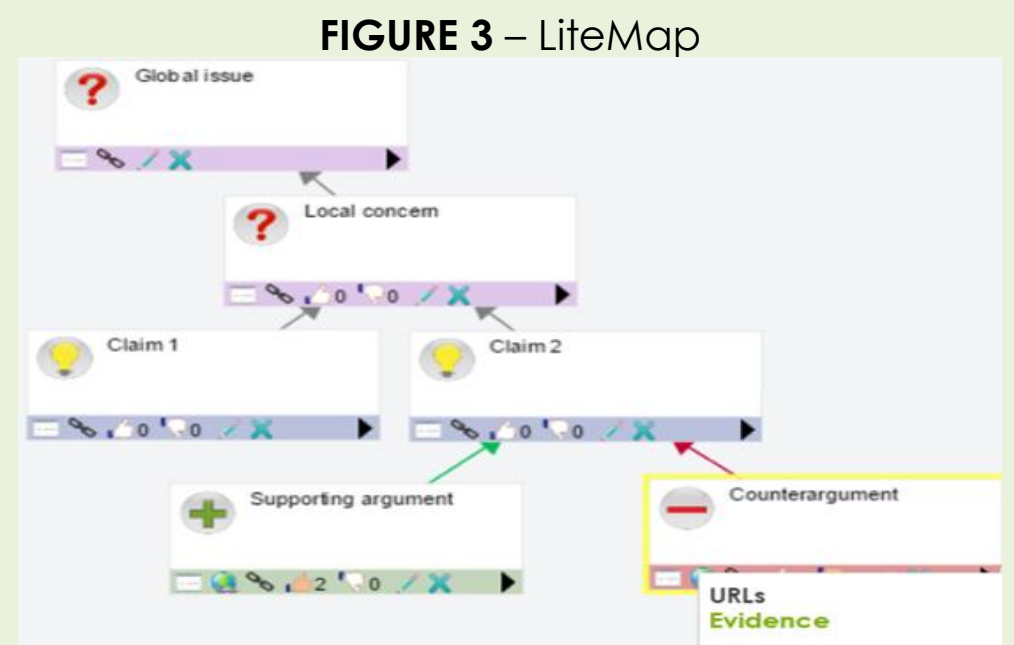

Source: Okada, 2010. Software tool: Word. 
Figure 3 described the key components of evidence-based dialogue mapping. Students with partners map global issues and local concerns, connect ideas (statements). Then they connect supporting arguments and counter arguments that are linked to evidence. The map enables participants to visualise questions that do not have answers, answers that are not connect with arguments and arguments that do not have evidence.

In order to present the benefits of using inquiry mapping for developing network thinking skills in research projects, we selected some principles (Jonassen, 2000) to analyse six models of maps (table 2): research map, reference map, reading map, theory map, fieldwork map and writing map.

TABLE 2 - Eliciting thinking skills through inquiry maps

\begin{tabular}{|l|l|l|}
\hline Inquiry Maps & Thinking skills & Research Steps \\
\hline Research Map & $\begin{array}{l}\text { Problem } \\
\text { solving, design }\end{array}$ & $\begin{array}{l}\text { Problematisation: map a brainstorm of questions in } \\
\text { order to find key issues }\end{array}$ \\
\hline $\begin{array}{l}\text { Reference } \\
\text { Rap }\end{array}$ & $\begin{array}{l}\text { Decision- } \\
\text { making }\end{array}$ & $\begin{array}{l}\text { Literature Review: map relevant sources of reference in } \\
\text { order to select key literature to ground your ideas. }\end{array}$ \\
\hline $\begin{array}{l}\text { Theory } \\
\text { Map }\end{array}$ & Evaluating & $\begin{array}{l}\text { Interpretation: map the content of the selected papers } \\
\text { to make sense of key concepts }\end{array}$ \\
\hline Fieldwork map & $\begin{array}{l}\text { Analysing } \\
\text { Elaborating } \\
\text { integrate a key body of knowledge }\end{array}$ \\
\hline Writing map & $\begin{array}{l}\text { Synthesising } \\
\text { Imagining } \\
\text { inquiry method to address the research questions }\end{array}$ \\
\hline $\begin{array}{l}\text { Synthesis: map key components of the research } \\
\text { process: issues, references, concepts, methods, data } \\
\text { and findings in order to visualise key arguments and } \\
\text { develop a coherent summary. }\end{array}$ \\
\hline
\end{tabular}

Source: Okada, 2010.

Literature about open schooling is limited as it is a recent concept. Previous studies about open schooling suggest that a key challenge is to support communities with practical participatory methods for engaging all multi-actors from schools, universities, enterprise, civil society and policy makers that enable them to develop real-world issue projects together (Okada \& Sherborne, 2018). To explore this gap, this exploratory study used inquiry mapping method, which was designed to support collaborative research facilitated by the network thinking method denominated 'inquiry mapping' method (Okada, 2008) applied by students with partners using various tools. 
The key research questions of this study are:

RQ1. In what ways do inquiry mapping method enable cooperation between students, teachers and STEM professionals and or their community?

RQ2. In what ways do inquiry maps support learners with network thinking?

To answer these questions this study presents the inquiry mapping approach, its foundations, examples analysed supported by qualitative study and provides some recommendations to foster open schooling projects in network.

\section{METHODOLOGY}

This exploratory study was supported by RRI, open data and open access participatory instruments.

This study focused on open schooling communities of the ENGAGE project, which was funded by the European Commission to enhance science education and increase the awareness of RRI with inquiry-based learning through partnerships between schools, universities and local community.

ENGAGE multi-language and multi-actor platform offered a set of introductory tasks (lessons); practicing fun activities (2 lessons) and open schooling scenarios-projects grouped in six categories: health (wellbeing), environment, transport, energy, technologies, science-society. Each scenario included open educational resources for educators, learners and partners to develop students-led projects. In addition, the platform provided a brokering partnership system for schools to interact with STEM professionals from universities and local community. A set of reflective and fun participatory tools for planning, development and self-assessment of open-schooling projects was also available in the platform to support network thinking and ten inquiry skills for RRI (Okada \& Sherborne, 2018).

These reflective participatory tools included: think-talk role-play, consequences and risk-analysis templates, gamification cards and boards for decision making and inquiry maps applications with tutorials and self- 
assessment guide, In addition, the platform included for each open schooling scenario an area for science teachers to add comments and examples of students-led projects, developed in various formats, media and tools; for example, scientist-interview, science report- blog, infographic poster, webinar-video, data map, map annotation.

To answer our research-questions by examining best practices obtained as secondary sources in this research - authors representing distinctive groups and fields used the self-assessment inquiry mapping guide which offers a set of criteria: elicit principles, inquiry map rubrics and aesthetic characteristics (Okada, 2010).

Elicit principles enable teams to evaluate network thinking represented in the inquiry map through six components for checking whether the project outputs contain:

(E)xplicit goals - clear goals, for example, questions or problem.

(L)earning actions - steps used to develop inquiry Project.

(I)nteresting information - relevant concepts, data, references.

(C)lear connections - coherent links, explicit lines of reasoning.

(I)ntegrated overview - organised summary, clear big Picture.

(T)rail signed route - visual marks, easy-to-follow traced pathways.

Inquiry mapping rubrics (Table 3) enable teams to evaluate inquiry components. Each rubric contains a question to assess the relevance of each component.

TABLE 3 - Eliciting thinking skills through inquiry maps rubric

\begin{tabular}{|c|c|c|}
\hline $\begin{array}{l}\text { Inquiry } \\
\text { Maps }\end{array}$ & Rubrics & Some questions to assess components of inquiry maps \\
\hline \multirow[t]{3}{*}{$\begin{array}{l}\text { Research } \\
\text { map }\end{array}$} & Research-Questions & $\begin{array}{l}\text { - Does your map present good research questions or } \\
\text { aims? }\end{array}$ \\
\hline & Research-Description & $\begin{array}{l}\text { - Is your research project well described through key } \\
\text { questions: } \\
\text { What? Why? For what? Who? Where? How? When? }\end{array}$ \\
\hline & $\begin{array}{l}\text { Research- } \\
\text { Knowledge }\end{array}$ & - Is your prior knowledge about the topic visible? \\
\hline \multirow[t]{2}{*}{$\begin{array}{l}\text { Referenc } \\
\text { e Map }\end{array}$} & $\begin{array}{l}\text { Reference- } \\
\text { relevance }\end{array}$ & $\begin{array}{l}\text { - Does your map indicate relevant references in the } \\
\text { search field? }\end{array}$ \\
\hline & Reference-quantity & $\begin{array}{l}\text { - Does your map show enough references to start your } \\
\text { study? }\end{array}$ \\
\hline
\end{tabular}




\begin{tabular}{|c|c|c|}
\hline & Reference -Structure & - Are your references well organised by key concepts? \\
\hline \multirow{3}{*}{$\begin{array}{l}\text { Reading } \\
\text { Map }\end{array}$} & Reading-Summary & - Does you map show a good summary of your text \\
\hline & Reading-Headings & $\begin{array}{l}\text { - Are the key concepts to structure your reading well } \\
\text { described? } \\
\text { (theme, relevance, aims, concepts, analysis, claims, } \\
\text { evidence, conclusion) }\end{array}$ \\
\hline & $\begin{array}{l}\text { Reading- } \\
\text { Understanding }\end{array}$ & - Does your map allow you to understand the content? \\
\hline \multirow{3}{*}{$\begin{array}{l}\text { Theory } \\
\text { Map }\end{array}$} & Theory-Relevance & - Does your map present relevant theory? \\
\hline & Theory-Viewpoints & -Does your map integrate different viewpoints? \\
\hline & Theory-Meaning & - Does your map allow you visualize new meanings? \\
\hline \multirow[t]{3}{*}{$\begin{array}{l}\text { Fieldwork } \\
\text { Map }\end{array}$} & Data-Relevance & $\begin{array}{l}\text { - Does your map present relevant data from your } \\
\text { fieldwork? }\end{array}$ \\
\hline & Data-Quantity & - Does your map show enough data for your study? \\
\hline & Data-Structure & $\begin{array}{l}\text { - Is your map well structure allow you find specific data } \\
\text { quickly? }\end{array}$ \\
\hline \multirow[t]{3}{*}{$\begin{array}{l}\text { Writing } \\
\text { Map }\end{array}$} & Writing-Structure & $\begin{array}{l}\text { - Does you map present a clear structure for you writing } \\
\text { about your research? }\end{array}$ \\
\hline & Writing-Connections & $\begin{array}{l}\text { - Does you map connect key-categories such as } \\
\text { context, hypothesis, aims, background, methodology, } \\
\text { findings, and considerations? }\end{array}$ \\
\hline & $\begin{array}{l}\text { Writing- } \\
\text { Understanding }\end{array}$ & $\begin{array}{l}\text { - Does your map help you write your understanding } \\
\text { about the topic? }\end{array}$ \\
\hline
\end{tabular}

Source: Okada, 2010.

Aesthetic characteristics (Table 4) enable teams to evaluate whether the inquiry map presents a clear and meaningful design.

TABLE 4 - Analysis of inquiry maps' aesthetic characteristics

\begin{tabular}{|l|l|}
\hline Rubric & Some questions to assess aesthetic characteristics of maps \\
\hline Structure & $\begin{array}{l}\text { Is the title of the map visible and clear? } \\
\text { Are the components and their connections well organized? } \\
\text { Are the relationships between objects well described? } \\
\text { Is the map easy to be understood? }\end{array}$ \\
\hline Content & $\begin{array}{l}\text { Does the map offer a global picture of its content? } \\
\text { Are the components relevant and clear? } \\
\text { Does the map achieve its purpose? } \\
\text { Does the map allow you to understand its content? }\end{array}$ \\
\hline Layout & $\begin{array}{l}\text { Is the design of the map clear? } \\
\text { Are the text and images well organized in the map? } \\
\text { Are the connections visible and easy to be identified? } \\
\text { Does the map allow you to read and browse its content easily? }\end{array}$ \\
\hline
\end{tabular}

Source: Okada, 2010.

These three sets of evaluation criteria were used to select best examples representing each of the six types of inquiry maps. 


\section{FINDINGS}

\section{Problematization with research maps}

In terms of cooperation (RQ1), figure 4 provides a "research map" created by research-students from secondary school who used the open schooling approach. Participants were 30 students, 2 science teachers, 1 electric car engineer. The research map about electric cars indicated the students' initial question supported by their science teacher "Is the electric car the best option of transport to reduce CO2 emissions?".

They used a template in power point to organise the key components of their inquiry study about electric cars, for example, dilemma (socioscientific issue), mobile data collection, data discussion, data map, photos, and dialogue maps, report).

Students interacted with an Engineer, and new questions emerged, for example, "What are the advantages and disadvantages of electric cars for people who live in Milton Keynes?", "What do parents of students in our school think about electric cars". Students also discussed with a Science Researcher about their hypothesis based on data that they found on the web. "If electric car is charged with electricity from renewable sources, then life cycle emissions of electric car are virtually zero". Students also talked with their family.

Some students had relatives who were owner of electric cars. The interaction with their own community helped them to share information with their peers and generate new questions, for instance, "Do electric cars produce fewer emissions?", "How green are electric cars?". "Would you buy an electric car?". The argument map created in LiteMap supported by an IT instructor helped students to connect questions, claims, pro-arguments, counterarguments and data. Students then used their map to write their blog report about "Electric cars save pollution. They are good for short drives" which was shared with their families and the engineer who supported them as a mentor. 


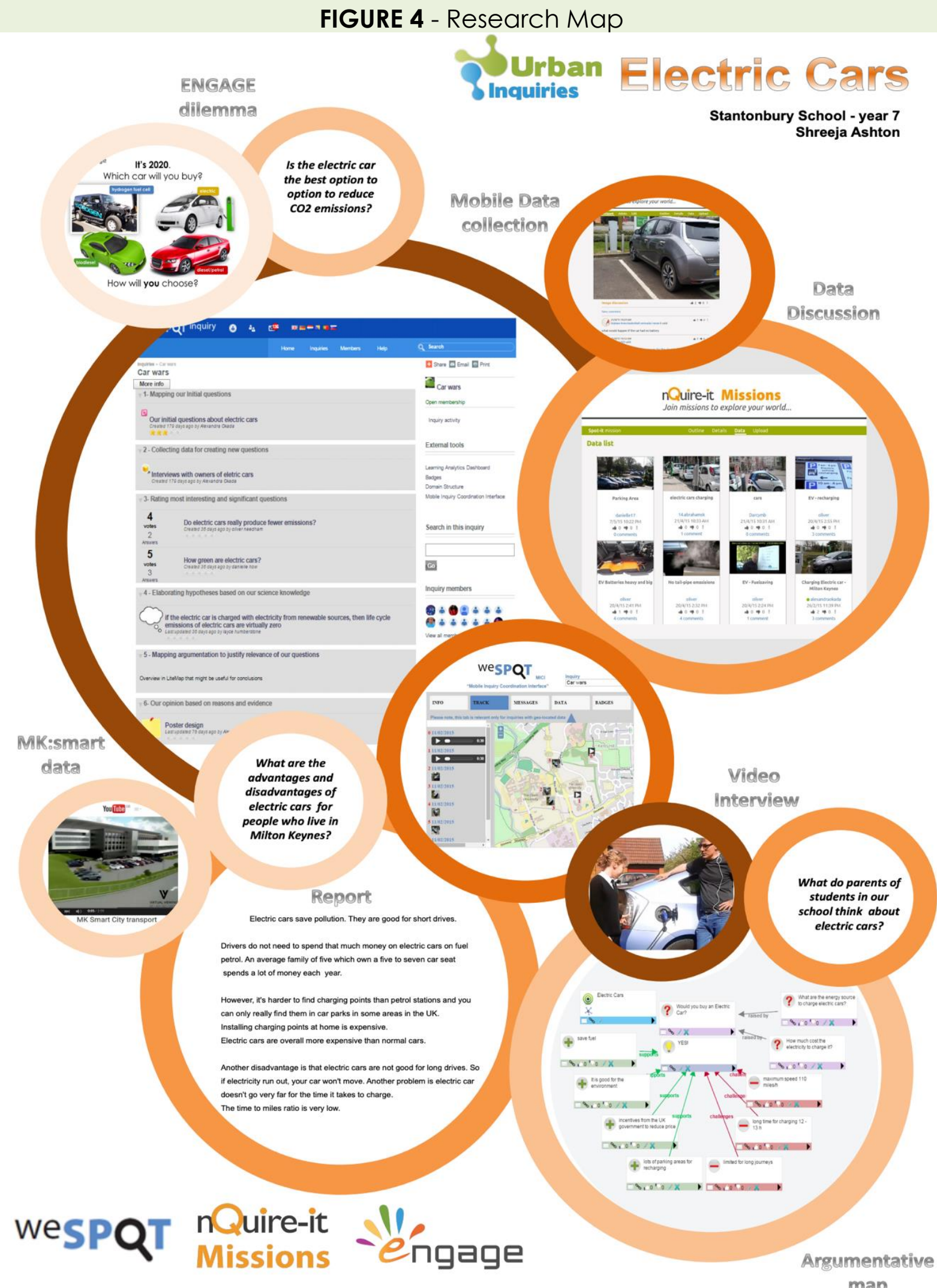

map

Source: ENGAGE Open Schooling - Research Map about Electric Cars (UK).

Author: Stantonbury Secondary School Students.

Participants and roles: 30 students (project lead), 2 science teacher (facilitator), 1 IT instructor (facilitator), 1 Electric Car Engineer (mentor).

Formal Learning Objective: Apply knowledge about atmospheric carbon dioxide and 
evaluate solutions to the problem of increasing carbon dioxide emissions from cars and justify opinions.

Deep Fun: car war game, real-life interviews, student-presenters in a conference.

Network thinking supported 6 skills: devise questions, interrogate sources, analyse data, draw conclusions, justify opinions and communicate ideas.

Tools used: weSPOT (Audio data collection Engineer interview), NQuire-it (Photo data collection with community and family members), ENGAGE (open schooling activity), LiteMap (writing map) Power Point (Research Map), Word (blog post).

In terms of network thinking (RQ2), this example revealed that good inquiry projects depend on significant questions. At the beginning of a research, it is not easy to define a relevant issue. Initially, research-students can be lost when they have to face lots of information without questions, or when there are many questions but no significant references. (Okada, 2008). Mapping the starting point of a research project with relevant partners helped students to find better questions.

\section{Reference map - Organising resources}

Figure 5 presents a reference map poster created by science-educator

that contains various types of resources and contributions from partners provided in Europe for students with their communities in Brazil to develop open schooling projects using inquiry maps.

In terms of cooperation (RQ1), students' partners were a biotechnologist and an environmental biologist researcher. The open schooling scenario was about ZIKA - "whether Aedes Egiptus mosquitoes should be or not exterminated" inspired by OXITEC company.

This inquiry map shows four references for students organised in 3 steps: a science knowledge food web game to initiate their inquiry; a set of societal actors' views cards for them to create the arguments, a risks $x$ benefits assessment template map for them to analyse and solve the socioscientific issue; and students' opinions based on evidence template map for them communicate their findings supported by their partnerships.

The reference map question illustrated why and how students should interact with scientists, companies and communities. Students in Europe were interested in "should mosquitos be exterminated"? The cooperation was 
established based on common interest. Oxitec company introduced a video showing how GM mosquito was used as a "vector control solution". The environmental scientist introduced a different proposal - denominated "." with a microorganism called "mesocyclops". The students in Brazil discussed what was then the best solution to reduced Zika in Brazil? Supported by information and scientists from Europe.

FIGURE 5 - Reference Map

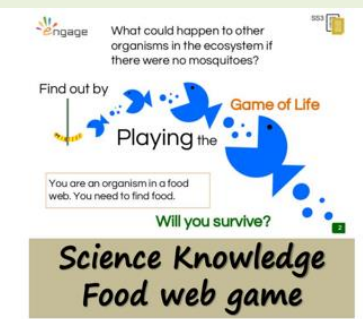

1. INQUIRY

Reflect on dilemma and devise their research questions.
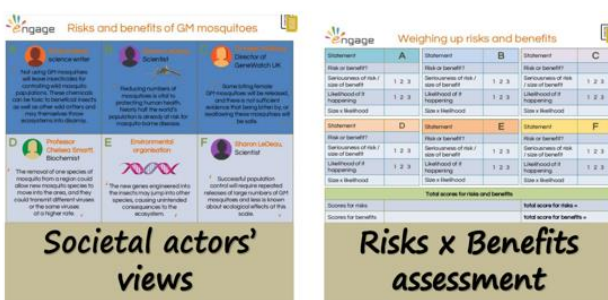

2. ANALYSE AND SOLVE

Interrogate sources, analyse data on GM technology to exterminate mosquitoes.

They estimate risks, examine consequences and use ethics to draw conclusions.

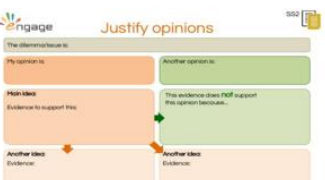

Students' opinions Based on evidence

3. COMMUNICATE

Choose an audience to critique claims and communicate ideas and way to justify their opinions based on evidence.

Why and how do students interact with scientists, companies and communities?

Should mosquitos be exterminated?
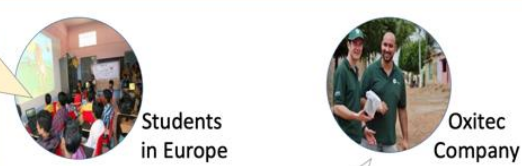

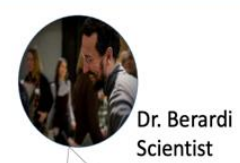

Mesocyclops is a "community owned controlling the Aedes mosquito population

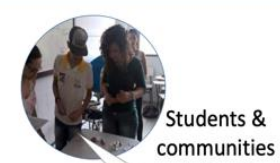

in Brazil

What is the best

alternative for reduce Zika in Brazil?

Source: ENGAGE Open Schooling - Reference Map about ZIKA.

Author: Open University - ENGAGE project coordinator.

Participants and roles: 200 students (project lead), 10 multidisciplinary teacher (facilitator), 1 biotechnologist, 3 Academic Researchers, 1 Biologist Environmental Researcher (mentor). Formal Learning Objective: Interdependence: Describe how a species' population changes as its predator or prey population changes.

Deep Fun: ecosystem-game, debate with scientist, science-action against ZIKA.

Network thinking supported 6 skills: Interrogate sources, estimate risk, use ethics, justify opinions and communicate ideas.

Tools used: ENGAGE (open schooling activity), Power Point (ResearchMap), Word (Risk Benefits - Reference Map), Mobile Phone Notes (Data Collection about Societal Actors' views).

In terms of network thinking (RQ2), mapping references on the web can help students search for significant information, interrogate sources, devise questions, for example, What are the key sources? What are the key theories, 
foundations, concepts and origins? What are the main articles, papers and other references? What are the main case studies? Is there any practical example? Who are the expert contacts that can provide feedback? What are the major debates about the topic? (Okada, 2010).

\section{Reading map - Interpreting and analysing text}

Figure 6 presents a reading map of a discussion between various participants interested in science teachers' professional development about Inquiry Based Science Education'.

In terms of cooperation (RQ1), participants were $\mathrm{PhD}$ research students, science educators, STEM project developers, curriculum designers and expert academics in biotechnology, environment and sustainable development. The map was created collaboratively with the facilitators using LiteMap annotation tool. The icons were added in the text using LiteMap BookMarklet tool with the browser, so any partner when activated it in their own equipment were able to see the icons added by their colleagues. The icons helped readers to identify components and lines of reasoning connecting questions, claims, arguments and counter arguments, as wel evidence (data) to support arguments. It also enables learners to identify areas that were not mapped.

The map shows a question by a science teacher: "How could we integrate teachers' professional development, IBSE and ethical dimensions in science teaching?", A claim was linked to the question by a science teachers' educator "ethical dimensions and values in education is part of our preparation of teachers and what children do (activities) in the classroom". A counter argument added by an academic researcher indicated that "it is not easy answer because working with ethics involves personal values and experiences and teachers get mixed messages". The screenshot of the reading map presented 3 questions, 3 claims, 3 pro arguments and 3 counter arguments from different participants. 
FIGURE 6 - Reading Map

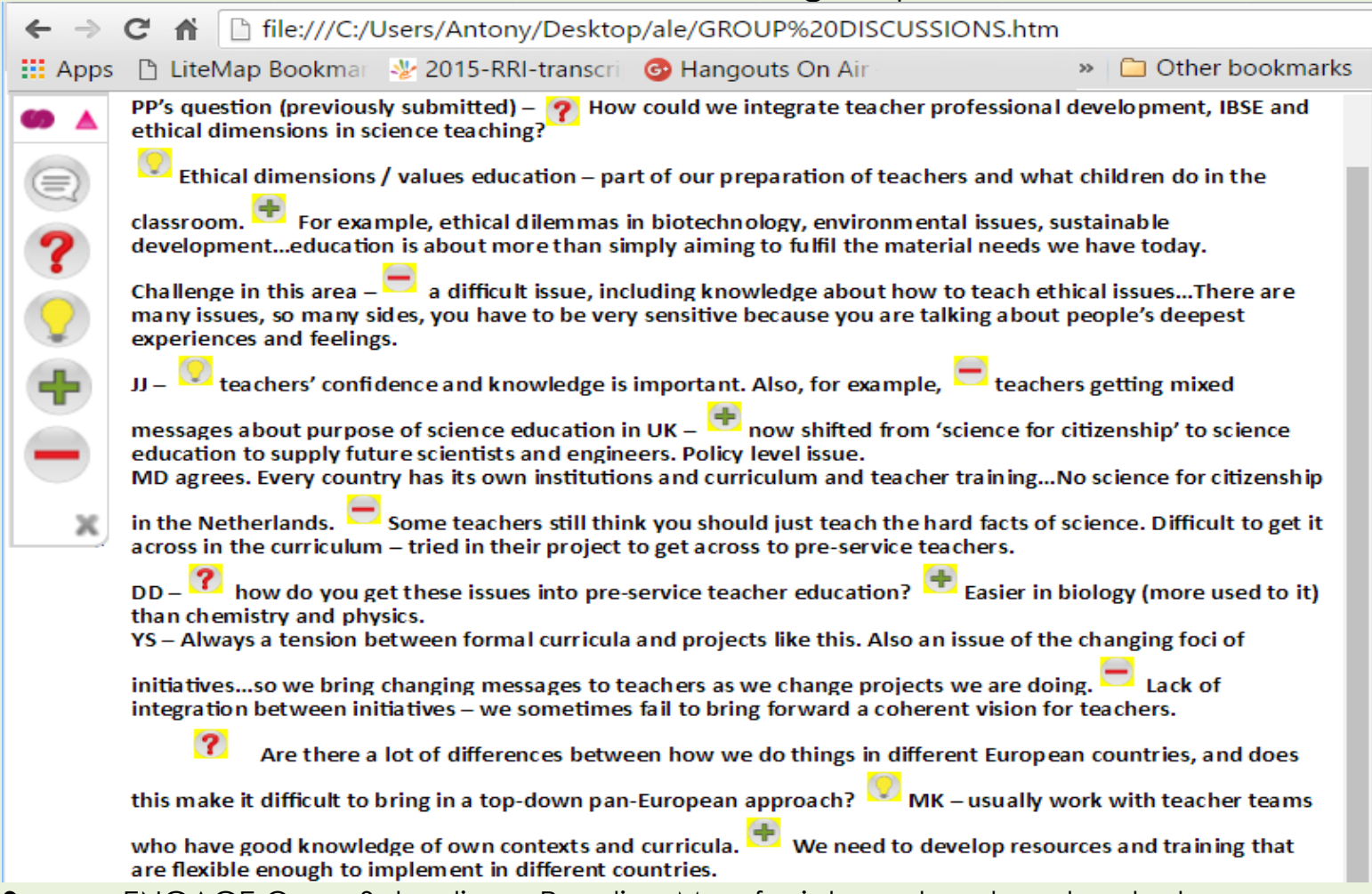

Source: ENGAGE Open Schooling - Reading Map for interpret and analyse text.

Author: ENGAGE Seminar team.

Participants and roles: 6 science education teachers, 2 curriculum developers, 3 academic experts, 1 project coordinator, 3 academic researchers (facilitator).

Formal Learning Objective: establish a research agenda map.

Deep Fun: debate, digital transcription, collaborative annotation, reading \& writing with fun Network thinking supported 6 skills: devise questions, Interrogate sources, use ethics, justify opinions and communicate ideas.

Tools used: ENGAGE (open schooling activities), LiteMap Annotation tool.

In terms of network thinking (RQ2) the reading map helped researchers summarise the document, and also examined, analysed and reviewed the content by visualising and re-connect the icons from different perspectives using the LiteMap canvas.

To annotate the map participants had to select relevant sentences and interpret it in context by attributing an icon, which provided some extra information about the discussion. The icons with content annotated were automatically captured into LiteMap and enabled participants to recombine and reconnect the annotation to cocreate new lines of reasoning. Interpretation implied in apprehending meanings by breaking up the complex text in simple parts. Mapping important statements of a document and their interrelationships using icons provided some clues for readers to 
interpret the content. Through reading maps, participants visualised what is important, to store and retrieve pieces of information quickly.

\section{Theory map - Understanding concepts}

Figure 7 present a theory map including three perspective: context (yellow), key concepts and description (blue). This conceptual map created in CMap Tools and discussed in Google hangout focused on the topic "Media, Education, Work and Society".

In terms of cooperation (RQ1), The map was created by an academic lecturer in Brazil to discuss a postdoctoral research project with feedback of eight participants from different areas. The map started with a question about "What are the key competences for Education to help learners become active socio-productive participant in society". In terms of content, four areas in yellow were connected: (1) Professional development; (2) Technology and social inclusion; (3) Higher Education; and (4) Management. Some key concepts were also presented in the map with connections to provide more details, for example: knowledge production, 21st century competencies, professional education and scientific methodology.

FIGURE 7 - Theory map

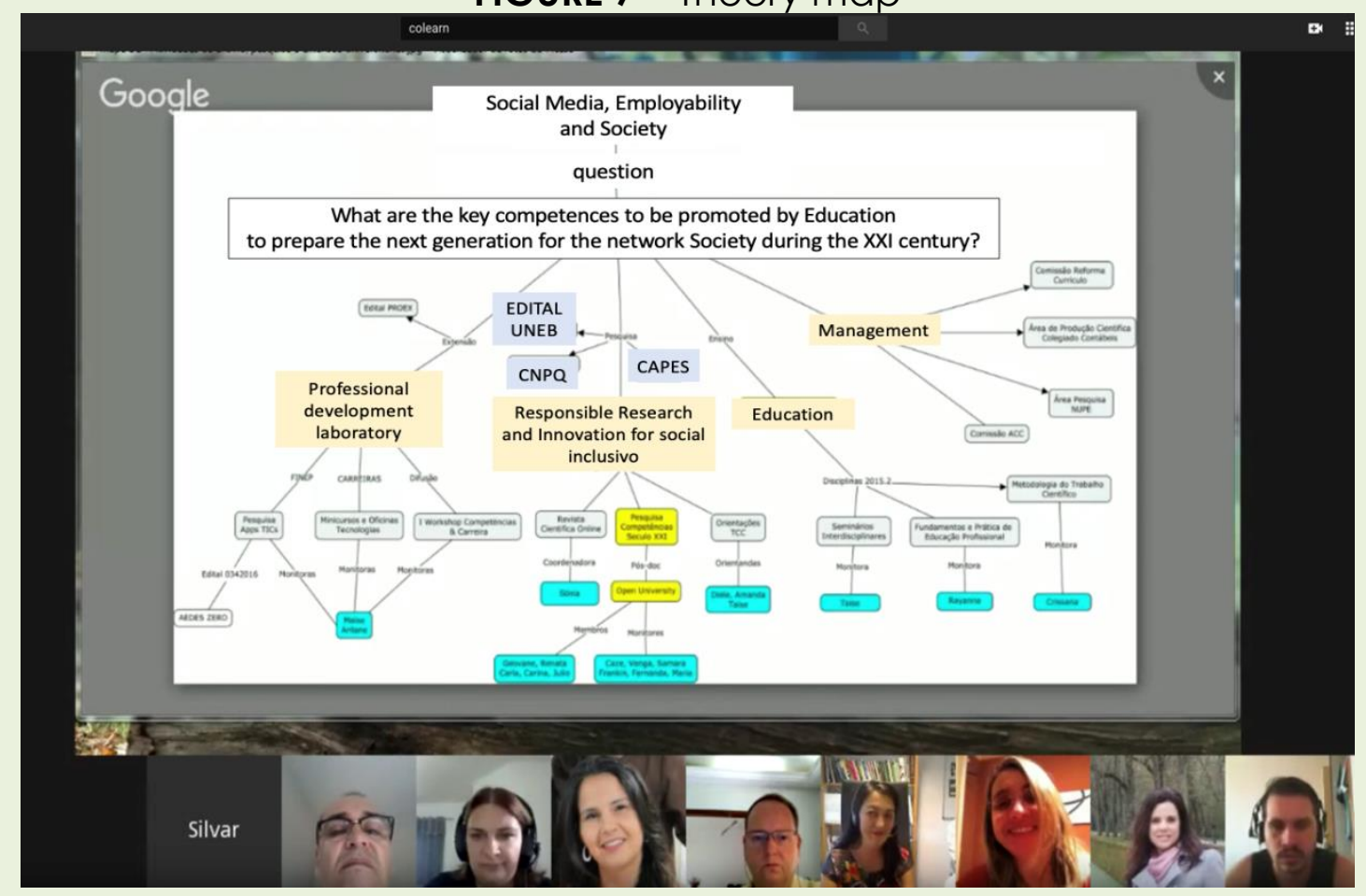

Revista Exitus, Santarém/PA, Vol. 10, p. 01-33, e020053, 2020. 
Source: ENGAGE Open Schooling - Theory Map about Competences and Employability. Author: Research Lecturer from Brazil - COLEARN COMMUNITY.

Participants and roles: 5 multidisciplinary educators, 3 Academic Researchers, 1 Biologist Science Educator, 1 Science Policy Advisor.

Formal Learning Objective: Peer-review about a post-doctoral proposal.

Deep Fun: Visual Map, Online Dialogue, Collaborative Peer Review.

Network thinking supported 6 skills: devise questions, Interrogate source, justify opinions and communicate ideas.

Tools used: ENGAGE (open schooling activity), CMap Tools and Google Hangout.

In terms of network thinking (RQ2), the theory map enabled the research-lecturer and partners to visualise and discuss connection between content, concept and its description. Clarifying concepts was an important step to understand theories and for receiving meaningful feedback.

Through well mapped concepts, experts and community members were able to visualise relevant components and its connections, compare, combine, comment and suggest new references. Mapping theories were good exercise for reflecting important principles to underpin a research project.

\section{Fieldwork map - Collecting and analysing data about the fieldwork}

Figure 8 provides a fieldwork map which contains various other nondigital maps developed by professional education school with teaching staff from various areas: agricultural administration, clinical analysis, commerce, nursing, environment, nutrition, advertising and occupational safety. The maps on paper were scanned using mobile phone and uploaded in LiteMap.

In terms of cooperation (RQ1), students were from 18 to 22 years old from Irecê which is a town widely affected by the ZIKA virus. Most of the students are from low income families and do not have access to computers. They created their non digital maps, which were organised and analysed in a fieldwork map as part of research data. Experts were than able to see the content, make comments and provide their feedback which was presented by the teaching staff to students using mobile devices. 
FIGURE 8 - Fieldwork map

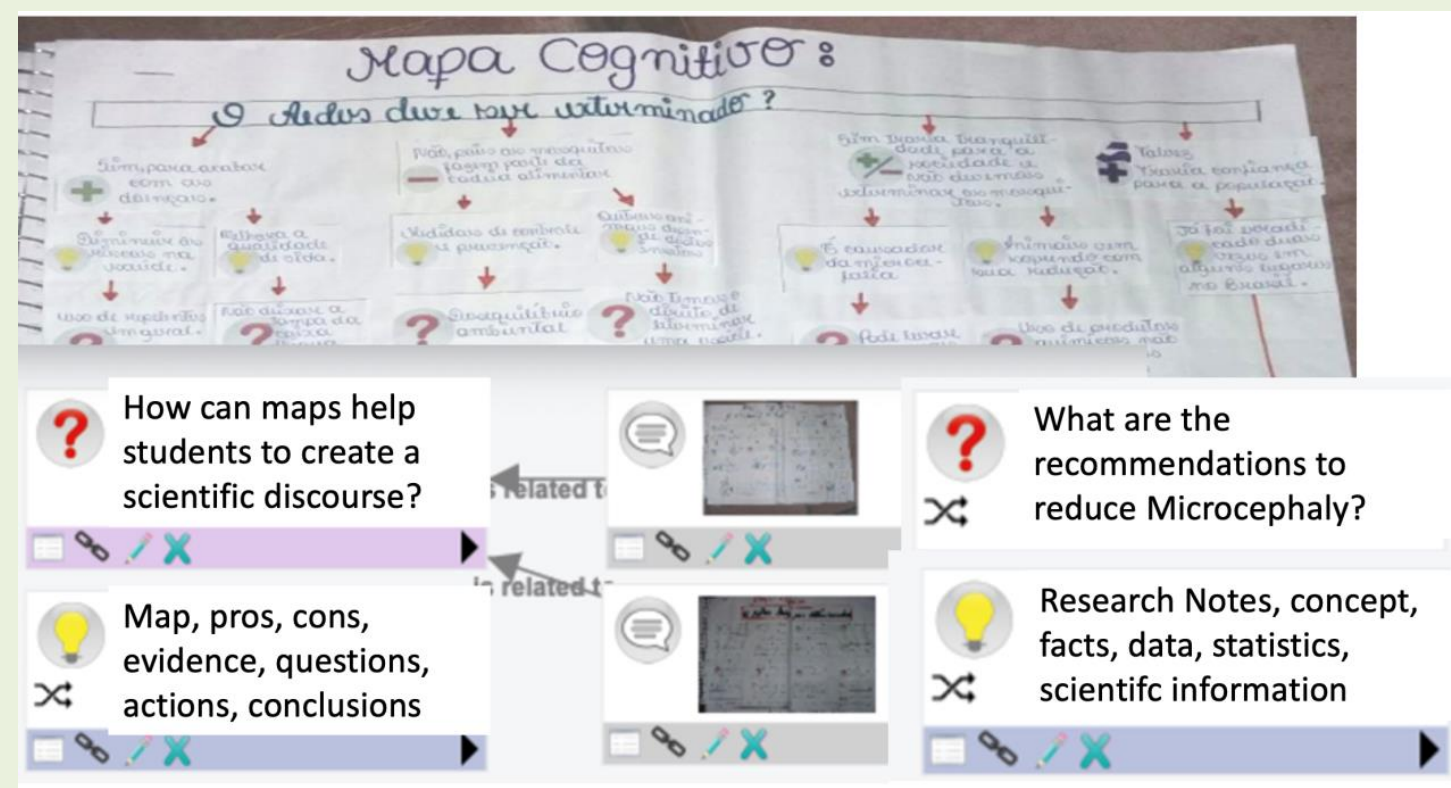

Source: ENGAGE Open Schooling - Reference Map about ZIKA.

Author: CETEP - Professional school (Brazil).

Participants and roles: 200 students (project lead), 10 multidisciplinary teacher (facilitator), 3 Academic Researchers, 1 Biologist Environmental Researcher (mentor.

Formal Learning Objective: Describe how a species' population changes as its predator or prey population changes.

Deep Fun: Interdependence game, Evidence-based Dialogue Map, digital inclusion.

Network thinking supported 6 skills: Interrogate sources, estimate risk, use ethics, justify opinions and communicate ideas.

Tools used: ENGAGE (open schooling activity), Power Point (ResearchMap), Word (Risk Benefits - Reference Map), Mobile Phone Notes (Data Collection about Societal Actors' views).

In terms of network thinking (RQ2), fieldwork map helped participants to organise group of data (maps and resources) and navigate across the sample, Each educational researcher of this project was able to create their fieldwork map and add the same components into their own canvas; they were able to navigate across maps that contained the same data but analysing based on different research questions and using different set of component. They were also able to make connections between the different fieldwork maps and interpretations Visualising and analysing key data through maps enabled participants to reorganise and connect multiple views and get an overview of the most relevant findings. 


\section{Writing map - systematising the research}

Figure 9 presents a report developed by a group of research and innovation team from Brazil and UK. The writing map included a video annotation indicating the key benefits and challenges of using mixed reality with Microsoft HoloLens to teach the components and functionalities of an electric motor. The writing map supported a scientific paper published in a peer-reviewed scientific edition of Computer Science.

In terms of cooperation (RQ1), the writing map summarised the research study and discussion of findings under the perspective of distinctive participants: students and partners involved in the project. Participants were a group of 25 students in mechanical engineering, 2 facilitators, the course team leader, a Computer Science professional, a Mechanical Engineer teacher and a STEM senior research educator.

FIGURE 9 - Writing map

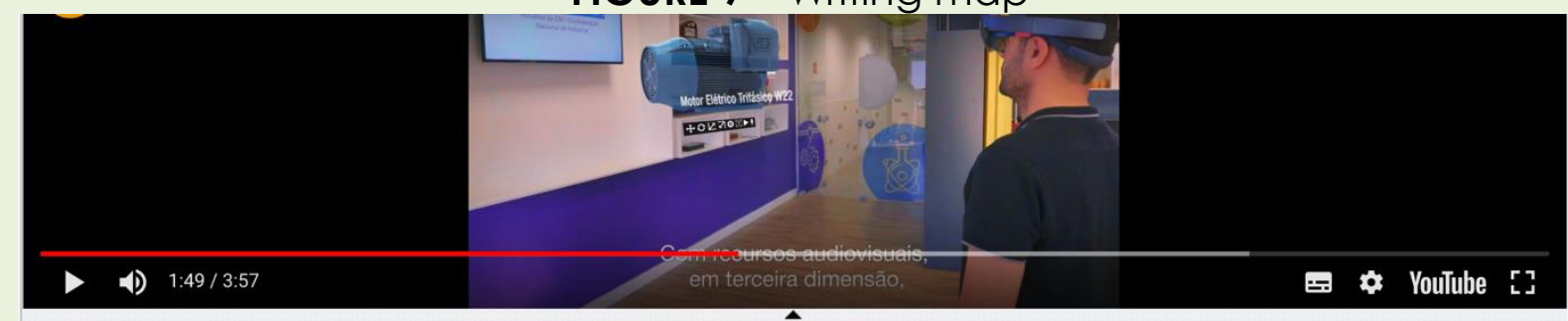

? What is the future of education for developing the professional of the future?

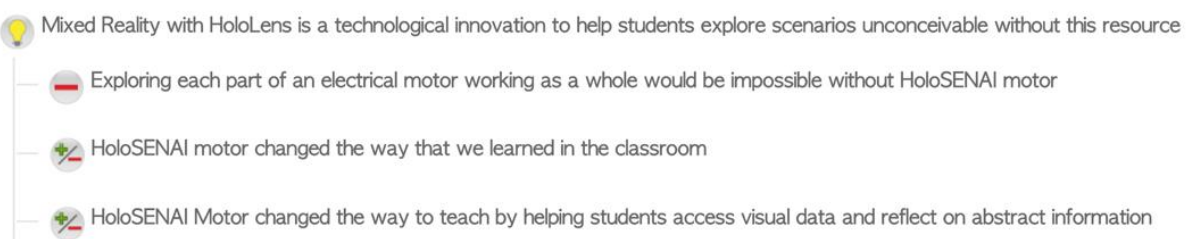

Source: ENGAGE Open Schooling - Future of Education for developing the professional of the future.

Author: SENAI Brazil and Open University UK.

Participants and roles: 200 students (project lead), 10 multidisciplinary teacher (facilitator), 3 Academic Researchers, 1 Biologist Environmental Researcher (mentor).

Formal Learning Objective: develop a scientific report and paper.

Deep Fun: Video-Map annotation, Multimedia writing.

Network thinking supported 6 skills: Interrogate sources, estimate risk, use ethics, justify opinions and communicate ideas.

Tools used: LiteMap, YouTube Video Clip.

The writing map presented distinctive participants' views linked to the video. It started by introducing a key question. "What is the future of 
education for developing the professional of the future? The head of the Institution added a comment "HoloLens is a technological innovation to help students explore scenarios inconceivable without this resource".

The course team mentioned that "pedagogical strategies such as situated scenarios enabled students to apply knowledge and skills to solve problems supported by peers and experts using HoloLens". Various benefits were presented (it help students to explore visual data, Students can reflect on abstract information). It also included some challenges as well (it requires teachers to change their lesson; the technology is very expensive).

In terms of network thinking (RQ2) Researchers and learners were able to describe and visualise key components of argumentation and its connections. The writing map provided a summary of key elements focussed on the main issues. Participants integrated all evidences including arguments that justify the conclusion. Through the writing map not only the outcomes were visualised but also how they were found and how the research problem was answered. It was useful to structure the paper to present the study and findings including the research's outcomes and conclusion.

\section{DISCUSSION AND RECOMMENDATIONS}

The central claim in this study is that making inquiry maps helps learners make their thinking explicit as well interconnected. Inquiry support students, teachers and partners with the metacognitive process of developing better thinking strategies collaboratively. The inquiry pathways represented by inquiry maps provide learners graphical representations for reflecting in action and reflecting about their own reflections during their research projects (Okada, 2010).

Analysing research components and data during an empirical study demands deep and systematic reflection Whyte (1991). Well designed inquiry maps can facilitate the process of analysis visually; mainly when all important components are connected in a well structured and coherent way. 
Findings from this study indicated that inquiry mapping was an useful method for open schooling for students to develop network thinking and cooperation between partners, which was significant to enhance network education. Through a set of best practice examples, inquiry mapping method provided:

- A set of principles and self-reflective tools to support network thinking.

- Different ways to apply inquiry maps led by distinctive participants.

- $\quad$ A variety of open schooling projects with inquiry mapping

- Meaningful ways that cooperation between school, university community and industry were implemented with inquiry maps to enhance open schooling.

- Interconnected instruments and tools to create and reuse maps in different scenarios.

Various examples of inquiry maps indicated learners and partners engagement their collaboration based and interconnected network thinking supported by common interests. The collaborative process of Inquiry mapping helped partners design reflect and shape questions, references, concepts, provide feedback practice key thinking skills through problem-solving interactions and collective building of knowledge (Okada, 2005). Baker (2003) emphasises that collaborative problem-solving and argumentative discussions help students choose better problem solutions and co-elaborate deeper understanding. McTighe (1992:190) also point out that the uses of graphical representations benefits students in at least four ways to:

1. Provide a focal point for group discussions by offering a commons frame of reference for thinking.

2. Provide a "group memory" or tangible product of the group's discussion.

3. Encourage students to expand their own thinking by considering different points of view.

4. Helps to articulate diverse lines of reasoning and helps to render the invisible process of thinking visible for all participants. 
As indicated by previous studies (Okada, Buckingham Shum \& Sherborne, 2008; Buckingham Shum \& Okada, 2014) some scholars argue that maps constructed by facilitators or partners might be difficult to be understood by other learners (Mayer, 2003). Representational notations in maps manifest also as constraints, presenting limits on expressiveness, and on the sequence in which knowledge units can be expressed (Suthers, 2003). From Zimmer's perspective "Maps can work well as a tool for one's own sensemaking, but not necessarily as a tool for transmitting knowledge to someone else" (Okada \& Connolly, 2008, p.12).

There are several factors involved for creating well-designed maps such as the learner's domain expertise, fluency with the tools, familiarity with mapping techniques, and the way in which their activity is designed. "Triggering students to critically check each other's information in order to maintain shared levels of understanding is useful and can be effectively provoked through task design, interface characteristics and the mode of communication" (Veerman, 2003:141). Provide them with structural patterns for better information visualization maximise knowledge understanding and search performance (Chen \& Czerwinski, 1997).

As explained, as graphical representations are useful for the development of the research cycle, according to the fundamentals of Llewellyn (2005). The representation of the search process can still be seen as a spiral, in a research perspective cyclical (Blaxter, Hughes \& Tight, 2001). However, according to your needs, the researcher will choose to perform all the phases present in the spiral or just a few steps in the process, based on the intensity of interactions of communities connected to the research network.

Research students must be also aware of issues such as: What is this map for? What am I trying to accomplish by using this map? What does this map show that I want to discover? What does this map show that I already know? What is missing in this map that I should include to make it clear? Is there anything that I could change in this map to make it more useful? What other situations and issues that this map can be useful for? 
Table 5 present some benefits of Inquiry Mapping for collaborative research, which supports this current work and also previous studies (Okada, 2006; Okada, 2010, Rocha, Rocha \& Okada; 2018).

TABLE 5 - Fostering network thinking skills through inquiry maps

\begin{tabular}{|c|c|c|}
\hline Inquiry Map & Network Thinking skills & $\begin{array}{l}\text { Benefits of Inquiry Mapping for open } \\
\text { schooling projects }\end{array}$ \\
\hline Research Map & $\begin{array}{l}\text { Problem solving: reformulate } \\
\text { questions, find new alternatives, } \\
\text { build acceptance } \\
\text { Designing: formulate goals, draft } \\
\text { outcomes, and revise process. }\end{array}$ & $\begin{array}{l}\text { 1.visualising the main ideas and } \\
\text { identifying the key questions that } \\
\text { most partners are interested in } \\
\text { 2.finding a common focus for } \\
\text { collaborative research. }\end{array}$ \\
\hline Reference Map & $\begin{array}{l}\text { Decision-making: identify } \\
\text { possibilities, generate } \\
\text { alternatives, and compare } \\
\text { options. }\end{array}$ & $\begin{array}{l}\text { 3. Identifying relevant literature with } \\
\text { collaborative recommendations } \\
\text { 4.group resources to support } \\
\text { different projects }\end{array}$ \\
\hline Reading Map & $\begin{array}{l}\text { Evaluating: define criteria, assess } \\
\text { information, recognise fallacies }\end{array}$ & $\begin{array}{l}\text { 5. Annotating ideas collaboratively } \\
\text { from texts } \\
\text { 6.Discussing meanings of key } \\
\text { concepts with support of partners }\end{array}$ \\
\hline $\begin{array}{l}\text { Theory } \\
\text { Map }\end{array}$ & $\begin{array}{l}\text { Connecting: compare and } \\
\text { contrast, infer deductively and } \\
\text { inductively, identify relationships }\end{array}$ & $\begin{array}{l}\text { 7.visualising connections and } \\
\text { pathways } \\
\text { 8.reconstructing new meanings }\end{array}$ \\
\hline Fieldwork map & $\begin{array}{l}\text { Analysing: recognise patterns, } \\
\text { classify main ideas, find } \\
\text { connections Elaborating: reflect, } \\
\text { widen and deepen, update, } \\
\text { concretise. }\end{array}$ & $\begin{array}{l}\text { 9. organizing a field work through } \\
\text { maps } \\
\text { 10. classifying and categorising data } \\
\text { 11. identify new issues to be clarified }\end{array}$ \\
\hline Writing map & $\begin{array}{l}\text { Synthesising: plan, hypothesise, } \\
\text { summarise. } \\
\text { Imagining: predict, speculate, } \\
\text { visualize. }\end{array}$ & $\begin{array}{l}\text { 12. Integrating questions ideas } \\
\text { arguments and evidence } \\
\text { 13. organising clear structure for } \\
\text { presenting collaborative thinking }\end{array}$ \\
\hline
\end{tabular}

Source: Okada, 2010.

\section{FINAL REMARKS}

This study highlights inquiry mapping method as a participatory method to engage multi-partners to identify relevant issues and build real issues scenarios to foster open schooling projects. Through six types of inquiry maps, this study indicates different uses of inquiry mapping to develop network thinking.

Inquiry maps created by research learners show that graphical representations are useful for developing the inquiry cycle (Llewellyn, 2005) and the spiral of research (Blaxter, Hughes and Tight, 2001). The inquiry 
mapping approach can be used integrating a subset or all six types of maps: Problematization, Literature Review, Interpretation, Conceptual Studies, Analysis and Synthesis. These six models of inquiry maps applied open schooling projects shows that visual thinking are useful for research-learners to implement research project supported by partners (Figure 2).

This study highlighted the role of network education in the digital age supported by network thinking. New studies will be useful to examine the correlation between network thinking and network literacy which includes knowledge media and socio-scientific network analysis. Examples discussed in this study shows that learners in partnership must be prepared to critically understand the network society and network education to make sense of the changes and challenges to make recommendations to shape research and innovation responsibly and together.

Six examples of open schooling projects show useful guidelines, templates, strategies and tools. To design, implement and evaluate open schooling practices, examples provided: scenarios, participants, experts and professionals, including their role, learning activities, inquiry skills, benefits, and outcomes, Our findings show different ways that inquiry map were used to promote interactions between learners, teachers, researchers, professionals in the scientific and technological fields, public policy and community engagement.

Inquiry maps can be considered strategic and heuristic artefact for representing what is important, interpreting and reconstructing meanings, recording and sharing new structures of components and connections. All of these skills are essential in conjunction with network thinking, network learning and network research to be supported by network education.

\section{ACKNOWLEDGEMENTS}

We are grateful to the network of researchers RRI-Network, in Brazil, for the partnership and availability of data from research maps for open school projects. This article is supported by previous studies, in particular by research Okada (2010) on maps in collaborative learning environments. 


\section{REFERENCES}

Archer, L., Dawson, E., DeWitt, J., Seakins, A., \& Wong, B. (2015). "Science capital": A conceptual, methodological, and empirical argument for extending bourdieusian notions of capital beyond the arts. Journal of Research in Science Teaching, 52(7), 922-948.

Baker, M. (2003). Computer-mediated argumentative interactions for the coelaboration of scientific notions. In J. Andriessen, M. Baker \& D. Suthers (Eds.), Arguing to Learn: Confronting Cognitions in Computer-Supported Collaborative Learning environments .Netherlands:. Kluwer Academic Publishers.

Blaxter, L., Hughes, C. \& Tight, M. (2001). How to Research. Buckingham: Open University Press.

Brydon, D. (2011). Globalization and higher education: Working toward cognitive justice. Valences of Interdisciplinarity: Theory, Practice, Pedagogy (97-120). Edited by Raphael Foshay Athabasca, AB: Athabasca University Press.

Buzan, T. (1993). The mind map book: Radiant thinking the major evolution ion human thought. London: BCA.

Shum, S. J. B., \& Okada, A. (2014). Knowledge cartography for controversies: the Iraq debate. In Knowledge Cartography (pp. 293-308). Springer, London.

Castells, M. (2010). A sociedade em rede. São Paulo: Paz e terra.

Chen, C. \& Czerwinski, M. (1997). Spatial ability and visual navigation: An empirical study. In: The New Review for Hypertext and Multimedia, Volume 3, pp. 40-66. http://research.microsoft.com/ marycz/nrhm.htm

Conklin, J. (2006) Dialogue Mapping: Building Shared Understanding of Wicked Problems. John Wiley, UK.

Cook, L.K. \& Mayer, R. E. (1988). Teaching readers about the structure of scientific text. Journal of Educational Psychology, 80, 448-456.

EC - European Commission (2015). HORIZON 2020 Work Programme 2014 2015: Science with and for Society. European Commission Decision C. <https://ec.europa.eu/programmes/horizon2020/en/h2020section/responsible-research-innovation>.

Edelson, D. C. (2001). Learning-for-use: A framework for integrating content and process learning in the design of inquiry activities. Journal of Research in Science Teaching, 38, 355-385. 
Ferguson, J. M. (2019). Networks, Globalization, and World Bank Education Strategies. New Proposals: Journal of Marxism and Interdisciplinary Inquiry, $10(1), 5-15$.

Freire, P. (1967) Educação como prática da liberdade. Paz e Terra, Rio de Janeiro.

Hmelo-Silver, C.; Duncan, R. \& Chinn, C. (2007) Scaffolding and Achievement in Problem-Based and Inquiry Learning. EDUCATIONAL PSYCHOLOGIST, 42(2), 99-107 Lawrence Erlbaum Associates, Inc. http://www.cogtech.usc.edu/publications/hmelo_ep07.pdf

Holst, J. (2006). Globalization and the future of critical adult education. Global issues and adult education: Perspectives from Latin America, Southern Africa, and the United States, 41-52.

Jonassen, D. (2000), Computers as mindtools for schools: engaging critical thinking. Upper Saddle River, N.J: Merrill.

Llewellyn, D.(2005). Teaching High School Science Through Inquiry: A Case Study Approach. NSTA.

Mayer, R. (2003). Learning and Instruction New Jersey: Merrill Prentice Hall.

McTighe, J. (1992). Graphic Organizers: collaborative links to better thinking. In: Davidson, N. and Worsham, T. Enhancing thinking through cooperative learning. New York, Teachers College, Columbia University Press.

Novak, J. (1998). Learning Creating and using Knowledge: concepts maps as facilitative tools in schools and corporations. London: Lawrence Erlbaum Associates Mahwah.

Okada, A. (2005). The Collective Building of Knowledge in Collaborative Learning Environments. In: Roberts, Tim S. ed. Computer-Supported Collaborative Learning in Higher Education, Volume 1. Idea Groups/IGI Global, pp. 70-99.

Okada, A. (2006). Cartografia Investigativa: interfaces epistemologicas comunicacionais para mapear conhecimento em projetos de pesquisa [Investigative Cartography: Epistemological and communicational interfaces to map knowledge in research projects]. Pontifícia Universidade Católica de São Paulo.

Okada, A. ed. (2008). Cognitive Cartography: Knowledge maps for research, education and teaching. CoLearn, 1 (1). Brasil: KCM.

Okada, A. (2010). Eliciting thinking skills with inquiry maps in CLE. In: Torres, Patricia \& Marriot, Rita eds. Handbook of Research on Collaborative 
Learning using Concept Mapping. Hershey, PA: Information Science Reference IGI Global, pp. 52-80.

Okada, A. (2014). Scaffolding school students' scientific argumentation in inquiry-based learning with evidence maps. In: Okada, A.; Buckingham Shum, S. J. \& Sherborne, T. (eds). Knowledge Cartography: Software Tools and Mapping Techniques. Advanced Information and Knowledge Processing. London: Springer London, pp. 135-172.

Okada, A. (2020). Deep fun for deeper learning. Proceedings of ASE International Conference January 2020 UK Readings.

Okada, A.; Buckingham Shum, S. \& Sherborne, T. eds. (2008). Knowledge Cartography: Software tools and mapping techniques. Advanced Information and Knowledge Processing, 1. London, UK: Springer.

Okada, A. \& Connolly, T. (2008). Designing Open Educational Resources through Knowledge Maps to enhance Meaningful learning. International Journal of Learning Technology, 15(7) pp. 209-220.

Okada, A. \& Rodrigues, E. A educação aberta com ciência aberta e escolarização aberta para pesquisa e inovação responsáveis. In Teixeira, C. S., \& de Souza, M. V. (2018). Educação fora da caixa. Editora Edgard Blücher.

Okada, A. \& Sherborne, T. (2018). Equipping the Next Generation for Responsible Research and Innovation with Open Educational Resources, Open Courses, Open Communities and Open Schooling: An Impact Case Study in Brazil. Journal of Interactive Media In Education, 1(18) pp. 1-15.

Okada, A. \& Zeiliger, R. (2003). The building of knowledge through virtual maps in collaborative learning environments. In: Telecommunications, Association for the Advancement of Computing in Education (AACE).

Ramos, A. L. M.; Korb, T. \& Okada, A. (2019). Immersive Analytics Through HolOSENAI MOTOR Mixed Reality App. In: Intelligent Computing:

Proceedings of the 2019 Computing Conference, Vol. 1, Advances in Intelligent Systems and Computing (AISC), Springer, pp. 1259-1268.

Rocha, A. K. L. T.; Rocha, A. B. L. T. \& Okada, A. (2018). Rubric to Assess Evidence-Based Dialogue of Socio-Scientific Issues with LiteMap. In: Technology Enhanced Assessment 20th International Conference, TEA 2017: Revised Selected Papers (Ras, Eric and Guerrero Roldán, Ana Elena eds.), Communications in Computer and Information Science, Springer, Cham, pp. 137-149.

Rosa, L. Q., Silva, R. S., Müller, F. M., Spanhol, F. J. \& Souza, M. V.(2018). Polo EaD como mídia do conhecimento na indústria 4.0. (2018). Anais do 
Congresso Internacional da ABED de Educação a Distância, Anais da ABED. Florianópolis - SC.

Ryan, C. (2015). Science Education for Responsible Citizenship. Report to The European Commission.

Souza, M. V. (2015). Mídias Digitais, Globalização, Redes e Cidadania no Brasil In Souza, M. V., \& Giglio, K. (Eds.). Mídias Digitais, Redes Sociais e Educação em Rede: Experiências na Pesquisa e Extensão Universitária. Editora Blucher.

Suthers, D. D. (2003). Representational Guidance for Collaborative Inquiry. In J. Andriessen, M. Baker \& D. D. Suthers (Eds.), Arguing to Learn: Confronting Cognitions in Computer-Supported Collaborative Learning Environments. Dordrecht: Kluwer.

UNESCO. Organização das Nações Unidas para a Educação, a Ciência e a Cultura. (2015). Educação para a cidadania global: preparando alunos para os desafios do Século XXI. Brasília: Unesco.

Van Gelder, T. J. (2002). Argument Mapping with Reason!Able. The American Philosophical Association Newsletter on Philosophy and Computers, 85-90.

Veerman, A. (2003). Constructive discussions through electronic dialog. In: Andriessen, Baker \& Suthers(Eds.) Arguing to Learn Confronting Cognitions in Computer-Supported Collaborative Learning Environments. Dordrecht: Kluwer.

Whyte, W. F. (1991). Participatory action research. Newbury Park, CA: Sage Publications.

Recebido em: 29 de fevereiro de 2020 Aprovado em: 21 de julho de 2020 Publicado em: 30 de julho de 2020

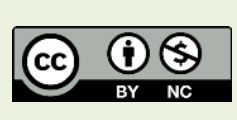

